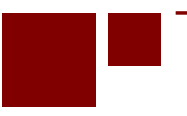

C E N T E R for RETIREMENT RE S E A R C H at BOSTON COLLEGE

\title{
WHAT CAUSES WORKERS TO RETIRE BEFORE THEY PLAN?
}

\author{
Alicia H. Munnell, Geoffrey T. Sanzenbacher, and Matthew S. Rutledge
}

CRR WP 2015-22

September 2015

\author{
Center for Retirement Research at Boston College \\ Hovey House \\ 140 Commonwealth Avenue \\ Chestnut Hill, MA 02467
}

Tel: 617-552-1762 Fax: 617-552-0191

http://crr.bc.edu

All of the authors are with the Center for Retirement Research at Boston College (CRR). Alicia H. Munnell is the Peter F. Drucker Professor of Management Sciences at Boston College's Carroll School of Management and director of the CRR. Geoffrey T. Sanzenbacher and Matthew S. Rutledge are research economists at the CRR. The research reported herein was performed pursuant to a grant from the U.S. Social Security Administration (SSA) funded as part of the Retirement Research Consortium. The opinions and conclusions expressed are solely those of the authors and do not represent the opinions or policy of SSA, any agency of the federal government, or Boston College. Neither the United States Government nor any agency thereof, nor any of their employees, makes any warranty, express or implied, or assumes any legal liability or responsibility for the accuracy, completeness, or usefulness of the contents of this report. Reference herein to any specific commercial product, process or service by trade name, trademark, manufacturer, or otherwise does not necessarily constitute or imply endorsement, recommendation or favoring by the United States Government or any agency thereof. The authors would like to thank John Scott for helpful comments and Christopher M. Gillis for excellent research assistance.

(C) 2015, Alicia H. Munnell, Geoffrey T. Sanzenbacher, and Matthew S. Rutledge. All rights reserved. Short sections of text, not to exceed two paragraphs, may be quoted without explicit permission provided that full credit, including $(\subset)$ notice, is given to the source. 


\begin{abstract}
About the Center for Retirement Research
The Center for Retirement Research at Boston College, part of a consortium that includes parallel centers at the University of Michigan and the National Bureau of Economic Research, was established in 1998 through a grant from the Social Security Administration. The Center's mission is to produce first-class research and forge a strong link between the academic community and decision-makers in the public and private sectors around an issue of critical importance to the nation's future. To achieve this mission, the Center sponsors a wide variety of research projects, transmits new findings to a broad audience, trains new scholars, and broadens access to valuable data sources.
\end{abstract}

Center for Retirement Research at Boston College

Hovey House

140 Commonwealth Ave

Chestnut Hill, MA 02467

Tel: 617-552-1762 Fax: 617-552-0191

http://crr.bc.edu

Affiliated Institutions:

The Brookings Institution

Massachusetts Institute of Technology

Syracuse University

Urban Institute 


\begin{abstract}
This paper explores the extent to which health, employment, family, or finances are associated with earlier-than-planned retirement using the Health and Retirement Study (HRS). The importance of any shock that drives early retirement depends both on its effect on those experiencing it and its prevalence in the population; therefore, the analysis proceeds in two steps. First, a probit regression is used to determine the strength of the relationship between the shocks and earlier-than-planned retirement, controlling for individual characteristics. Second, to incorporate the prevalence of the shock, counterfactual experiments are run to determine how much early retirement would be reduced in the population if these shocks did not occur.
\end{abstract}

This paper found that:

- Workers in poor initial health and workers who experience worsening health prior to their planned retirement date are significantly more likely to retire early than others.

- Workers with retiree health insurance are slightly more likely to respond to health shocks by retiring early, but because the estimate is statistically insignificant, more research is needed to establish whether the Affordable Care Act (ACA) will induce workers with deteriorating health to retire earlier.

- Workers who are laid off, workers whose spouse retires before their planned retirement date, and workers whose parents move into their home are also significantly more likely to retire early than others.

- Job-to-job mobility makes workers more likely to reach their retirement plans, but only if the new job is less stressful, requires fewer hours, or is higher paid than the old one.

- Health is the most important driver of early retirement, followed by layoffs or business closings, and then familial factors. Changes in finances play at most a small role.

The policy implications of this paper are:

- To the extent health improves in the future, workers may be better able to realize their retirement plans, leading to later retirement dates.

- The ACA is unlikely to significantly increase early retirement.

- Periods of high involuntary job loss are likely to be associated with earlier-than-planned retirement, although those who do find new work can meet their original plans. 


\section{Introduction}

Many workers seem to have internalized the message that working longer is one way to bridge the gap between retirement needs and resources. Between 1991 and 2014, the percentage of workers indicating that they planned on working past age 65 increased from 11 to 33 percent. ${ }^{1}$ But for many, these later retirement plans are not actually achieved. For example, in the Health and Retirement Study's (HRS) initial cohort, roughly 37 percent of those working at age 58 retired earlier than they were planning. ${ }^{2}$ Past research has identified several potential causes of earlier-than-planned retirement, including poor health, changes in marital and spousal employment status, and changes in retirement wealth. Yet, because these prior studies tend to focus on at most a few of these shocks, rather than all of these factors together, which factor is most important in determining earlier-than-planned retirement is unclear. Furthermore, little is known about the interaction between health deterioration and retiree health insurance (RHI), despite this issue's importance in predicting the effect of the Affordable Care Act (ACA) on the timing of retirement. If health insurance outside of employment allows workers to respond to deteriorating health by retiring before they planned, then the ACA, by offering all employees a health insurance option outside employment, may encourage earlier-than-planned retirement. ${ }^{3}$

This paper uses data from the HRS to estimate a model of early retirement and determine the relative importance of four different sets of "shocks" that may induce someone to deviate from their retirement plans. The first type of shock is changes to an individual's health. Because workers may "self-justify” their early retirement by claiming their health got worse, the paper analyzes changes in objective health measures, such as the appearance of activity-limiting arthritis, instead of relying on self-reported health. ${ }^{4}$ The effect of health shocks is allowed to differ based on whether a worker has health insurance outside of employment through RHI. The assumption is that workers with health insurance can retire after a health shock, whereas those without may have to persevere until Medicare is available. The second type of shock is employment changes - either shifting employers or losing of a job due to layoff or business closings. The third type of shock includes familial changes such as a spouse's retirement, the

\footnotetext{
${ }^{1}$ Employee Benefit Research Institute (2014).

${ }^{2}$ Authors' calculations from the study's sample.

${ }^{3}$ Indeed, the Congressional Budget Office (2014) reports that the ACA will reduce employment by the equivalent of 2 million full-time-equivalent jobs by 2017, much of it because older workers will no longer be required to continue working to maintain affordable health insurance coverage.

${ }^{4}$ Sensitivities were run using subjective health measures but this was less predictive of early retirement than the objective measures used.
} 
declining health of a spouse, a change in marital status, a resident child leaving the home, having one's parent move into the home, and having grandchildren. The final type of shock considered is a significant change in financial wealth. By including all these shocks together in a model of early retirement, this paper is able to quantify their relative importance to the common phenomenon of early retirement.

While the focus of the model is on changes in a worker's life that may precipitate early retirement, we also control for more static characteristics of the individual. In theory, characteristics known to workers at the time they make their retirement plans should be incorporated into this planning and thus not affect the probability of early retirement. ${ }^{5}$ However, it seems possible that a worker's ability to accurately forecast his retirement age is a function of individual characteristics that may also be correlated with shocks (e.g., a person with less education may inaccurately plan his retirement and also be more likely to experience a job loss). For this reason, we include a worker's demographic characteristics and other variables (e.g., pension status, health status) collected at the time the retirement plan was made as controls in the model. In practice, and consistent with theory, the results show that the characteristics of an individual at the time of retirement planning do not matter much in the model, with the important exception of a worker's initial health status.

This paper contributes to a limited body of research on the relationship between selfreported retirement plans and realizations. ${ }^{6}$ Several studies in this literature have found that a deterioration in health status precipitates early retirement (see Örestig, Strandh, and Stattin 2013, Munnell, Jivan, and Triest 2004, Dwyer and Hu 2000, and Disney and Tanner 1999). Other correlates of early retirement include changes in marital status (Disney and Tanner 1999), increases in Social Security benefits (specifically the Social Security "notch,” as in Anderson 1985), and the presence of pensions and early-out offers at the worker's employer (Dwyer and Hu 2000). Munnell, Jivan, and Triest (2004) are the only authors to examine the effect of job changes on early retirement, and they find that switching jobs reduces the risk of early retirement. These studies have not examined the role of spousal retirement, layoffs and business

\footnotetext{
${ }^{5}$ This theoretical result is one outcome of the "rational expectations" model, which predicts an individual's plans for the future incorporate any information available at the time they are made. Benítez-Silva and Dwyer (2005) confirm that retirement expectations are generally consistent with the rational expectations model.

${ }^{6}$ It is worth noting that several studies examine how retirement expectations change over time, including Benitez and Dwyer (2005), McGarry (2004), and Honig (1996). These studies, however, do not examine the correspondence between retirement expectations and actual retirement behavior.
} 
closings, and the interaction of RHI and health in causing disruptions in retirement plans. Taking a slightly different approach, Benítez-Silva and Dwyer (2005) look at how various variables impacted an individual's retirement expectations, but do not examine whether those expectations were met. While the preceding papers are informative, they differ in the variables considered and either use data that is now outdated or from another country (as in the case of Örestig, Strandh, and Stattin 2013 and Disney and Tanner 1999). Therefore, which factors are most associated with workers deviating from their planned retirement dates is unclear.

Our results indicate that health is the most important factor in earlier-than-planned retirement, followed by involuntary job loss, and then changes within the family, especially a spouse's retirement and having a parent move into the house. Changes in financial wealth do not have a significant impact on the probability of early retirement. Health is associated with early retirement in two ways: 1) workers in bad health when making their retirement plans are more likely to retire earlier than others, even if their health does not change; and 2) a deterioration in health leads to earlier-than-expected retirement. The estimates indicate that if all individuals made their plans in the absence of any negative health conditions and experienced no health shocks, then early retirement would fall by 4.8 percentage points, from the current rate of 37.0 percent to 32.2 percent. If no workers experienced involuntary job loss, the reduction in early retirement would be smaller, at 1.9 percentage points, and if workers' familial situation remained stable (e.g., no spouse's retirement, no change in marital status, no children exiting the home, no parents moving in), the reduction would be 1.6 percentage points. Interestingly, if all shocks associated with early retirement and poor initial health are removed, the decrease in earlier-thanplanned retirement is 9.9 percentage points, leaving an unexplained 27.1 percent of individuals retiring early. This finding suggests that idiosyncratic, hard-to-measure factors may have greater influence, such as job satisfaction, outside employment prospects, or the attractiveness of leisure time, and marks a direction for future research.

Aside from identifying which factors are most important in leading to early retirement, this paper has a particular interest in the impact of job instability - either through job-to-job movement or through layoff - and in the effect of health insurance outside of employment on early retirement. Interest in job mobility stems from the fact that the share of workers who change jobs in their 50s has increased sharply since the early 1980s, with about half of all 
workers at ages 58-62 no longer employed by their age-50 employer. ${ }^{7}$ Interest in outside options for health insurance stems from its application to the ACA. We find that workers who switch jobs are less likely to retire early than those who do not, suggesting increased mobility may allow workers to better achieve their retirement goals. Importantly, job-to-job movement only prevents early retirement when the new job is a "better job" with fewer hours, more pay, or less stress than the prior job. If the new job is worse, workers are actually much more likely to retire early, suggesting that not all mobility is productive. Workers with RHI are not significantly more likely to retire early in response to a health shock than workers without these outside sources of health insurance. This finding indicates that increased access to health insurance outside of employment through the ACA should not have a large effect on early retirement.

\section{Data}

This paper uses data from waves 1-11 of the HRS, collected between 1992 and 2012, to estimate a model of early retirement. The initial sample consists of all individuals in the HRS and War Baby cohorts working at the interview closest to their $58^{\text {th }}$ birthday (the "age-58 interview”) and who either 1) retired by 2012 or 2) did not retire, but had reached their planned retirement age by 2012 and thus had not retired early. ${ }^{8}$ The original HRS cohort consists of individuals born between 1931 and 1941 and who are typically 71 to 81 years old in 2012. Approximately 88 percent of these workers have retired by the end of the sample. The next oldest cohort, the War Babies, consists of individuals who were 65 to 70 in 2012 and who are less likely to have completed their careers, with roughly 76 percent having retired by 2012 . Since it may be the case that retired War Babies do not represent the experience of the average individual with respect to early retirement because less of their careers are observed, we include a cohort control in our model.

The first step is to identify when each worker planned to retire. At the age-58 interview, each working individual is asked "at what age/year do you plan to stop working?" For individuals who answer the question with an expected year, this answer is taken as their planned retirement date. For individuals who answer they "don't know" when they plan to retire, a second question is asked regarding when they think they will retire. If an individual answers this

\footnotetext{
${ }^{7}$ Munnell and Sass (2008).

${ }^{8}$ If an individual is not present at their age-58 interview, their next closest interview is used which may occur at either a younger or an older age.
} 
second question with a year, it is used as the planned retirement date. ${ }^{9}$ Using these two questions to assign planning dates results in approximately 55 percent of our sample being assigned a planned retirement date. However, some individuals report they "never” plan to (or think they will) retire. For these workers, the planned retirement age is found by following the individual from wave-to-wave and identifying the next time they report an actual planned retirement age. Table 1 shows the distribution of "planning ages" at which individuals' expected retirement age is collected, as well as the share retiring early for each planning age. About 84 percent of the sample has a planning age within a two-year window around age 58, meaning that many people who give a "never" answer at age 58 give a planned year in the next wave. However, the existence of "never" respondents means some individuals report their retirement age much later than 58 - this result could be concerning if individuals with later planning ages also have more or less accurate plans. In the analysis, two approaches are taken to account for this possibility: 1) we include a control indicating an individual's status as a "never" respondent; and 2) we conduct our analysis excluding these individuals. Fortunately, Table 1 also shows no clear pattern between the planning age and the share retiring early, suggesting the issue may be of little importance in practice. ${ }^{10}$

The next step is to identify workers who retired earlier than they planned - the dependent variable in the empirical analysis. The actual retirement age is the earliest age at which the HRS respondent reports being fully retired; partial retirements are not considered. Any worker who claims to be fully retired at least one year prior to his planned retirement age is said to have retired early. Individuals are included in the sample as long as they are observed either: 1) retiring early; or 2) remaining in the sample past their planned retirement date, which ensures that they have not retired early. Individuals who exit the sample prior to their planned retirement date are not included because it is unclear whether they would have retired early. The window between someone's planning age and their planned retirement age is the period during which "shocks" can occur.

\footnotetext{
${ }^{9}$ We find that approximately 6 percent of our sample answers both questions at their age-58 interview with "don't know." These individuals are not included in the analysis.

${ }^{10}$ Benitez-Silva et al. (2008) assign age 77 - one year more than the largest reported expected retirement age - to respondents with missing expected retirement ages, but find that using a different age makes little difference.
} 


\section{“Shock" Variables}

Once an individual's planned retirement age has been identified, it is possible to determine what aspects of his life changed in the years between the planning age and the planned retirement age. The four broad categories of shocks include: 1) health; 2) employment; 3) familial; and 4) financial. To identify shocks, the first step is identifying the individual's situation at their planning age and the second is to identify changes that occur between the planning age and their planned or actual retirement date (whichever occurs first).

To identify an individual's initial health and health changes, the literature typically follows one of two approaches: 1) using self-reported health; or 2) using a measure of objective health. In the first approach, researchers use an individual's response to a question where he labels his health as "Excellent”, "Good”, "Fair”, or "Poor."11 In the second approach, information on specific health conditions are collected and used as a proxy for health. ${ }^{12}$ We choose the latter approach, since we are concerned that a person deviating from their plans and retiring early may attempt to justify their actions by reporting worsening health (Altindag, Schmidt, and Sevak 2012). This "justification bias" is less likely to occur with objective measures. To identify a person's initial health, we create indicator variables for 13 health conditions that are asked about in each wave of the HRS and add them up at the individual's planning date to create an initial health index taking on a value of 0 (best health) to 13 (worst health). ${ }^{13}$ A similar index, albeit using a slightly different set of health indicators, was used by Dwyer and Mitchell (1999). The magnitude of the health shock an individual experiences is measured by taking the maximum health index between their planning age and their planned retirement age and subtracting their initial value. For example, a person who had two health conditions when they set down their retirement plans but at some point between then and retirement had five health conditions would get a health shock value of three. Because RHI may allow workers experiencing health shocks to retire earlier than others without it, the health shock variable is also interacted with a variable indicating the availability of health insurance outside of

\footnotetext{
${ }^{11}$ For example, see Munnell, Jivan, and Triest (2005).

${ }^{12}$ For example, see Dwyer and Mitchell (1999).

${ }^{13}$ These 13 conditions include eight health conditions and five limitations to activity of daily living. The health conditions included are: 1) "high blood pressure with medication"; 2) "diabetes with insulin"; 3) "cancer of any kind, seeing doctor”; 4) "activity limiting lung disease”; 5) "heart condition, taking medication”; 6)

"emotional/psychological problems"; 7) "stroke with problems afterward"; and 8) "arthritis with medication.” The limitations to activities of daily living are: 1) "needs help bathing”; 2) "needs help getting dressed”; 3) "needs help eating”; 4) "needs help using a map"; and 5) "needs help walking."
} 
employment, either through an individual's current employer, a past employer, or a spouse's employer.

This paper considers two types of employment shocks: 1) a new employer; and 2) loss of employment due to a layoff or business closing. Both of these changes are easily identifiable in the HRS; the survey asks each worker whether they are at the same employer as the prior interview and also whether they lost their job from the previous interview due to a layoff or business closing. The same individual can experience both kinds of changes: he lost his job but found re-employment at a new employer. Interacting the two variables - by creating an indicator for having a different employer after a layoff or business closing - allows for individuals who find a new job after an involuntary separation to differ from both individuals who changed employers voluntarily and from individuals who never found re-employment. The intuition is that individuals who find a new job after a layoff or business closing may have found that job under duress and thus may be more likely to retire early than workers who moved without such a disruption. To explicitly control for this possibility, some specifications control for characteristics of the new job, including whether it: 1) pays more; 2) is less stressful; 3) requires fewer hours; or 4) is less physical.

Regarding familial changes, we consider seven types of changes: 1) marital status; 2) spousal employment/retirement; 3) spousal health (using the same health index); 4) the presence of resident children; 5) having a first grandchild; 6) having a parent move into the respondent's home; and 7) having to take care of a parent even if they did not move in. At the individual's planning age, we identify marital status, the spouse's employment, the spouse's health, the presence of children in the household, the presence of grandchildren, and the individual's parental care status. Any change in these circumstances prior to the planned retirement date is then defined as a shock. Individuals who are not married or do not have children at their planning age are assigned zeros for these shocks.

Finally, we include measures of shocks to financial wealth. Initial financial wealth is the sum of assets held in stocks, bonds, CDs, and other types of financial accounts minus debt at the individual's planning age; this measure does not include housing wealth or defined benefit pensions. We include separate indicators for gains or losses of 50 percent of the initial financial wealth to allow for asymmetric responses to financial shocks. ${ }^{14}$

\footnotetext{
${ }^{14}$ Other specifications of the financial shock were attempted and are discussed below.
} 


\section{“Initial” Variables}

In theory, the only variables that should induce someone to retire earlier than planned are things that change between the time they made the plan and their retirement, i.e., the shock variables above. That is, anything known by the individual at the time of their plan should be incorporated in those plans and thus would not have an impact on the likelihood someone finds themselves retiring early. For example, even though we may expect blue-collar workers to retire earlier than white-collar workers because the work is more physical, blue-collar workers should know this and incorporate it into their expectations. At the same time, if some individuals are, say, better planners, then ignoring these initial characteristics could bias the estimates of the impact of shocks. For example, if high school dropouts tend to overestimate how long they will work and also have more frequent health shocks, then ignoring education will overestimate of the importance of health shocks in leading to early retirement.

To account for this possibility, we include a vector of demographic and other "initial" characteristics that are associated with the initial retirement expectations. The demographic variables include an individual's education (less than high school, high school graduate, some college), race, Hispanic origin, gender, and region. Initial variables related to the individual's employment status include self-employment, indicators for the presence of a defined benefit (DB) or defined contribution (DC) pension at a prior job, status as a white-collar employee, as well as characteristics of the individual's job such as whether the respondent reports it is stressful or requires physical exertion. In addition, the initial characteristics associated with the shocks described above are also included in the empirical specification; for example, controlling for the initial value of the health index differentiates between two individuals with the same health shock: one person whose index increases from having no conditions to two conditions, and another from seven conditions to nine conditions.

\section{Descriptive Statistics}

Table 2 summarizes the frequency of shocks as well as the share of individuals experiencing the shock who retire early. Any given shock, to be important, must meet two criteria: 1) it occurs frequently; and 2) it is associated with early retirement for those experiencing it. A shock that occurs infrequently will not be a major driver of early retirement in the population even if everyone who experiences it retires early. 
One of the most common types of shocks is a health shock, with 39.9 percent of individuals experiencing an increase in their health index prior to their planned retirement wave. Having a spouse retire and experiencing a layoff or business closing are two other common shocks, with 19.7 percent having a spouse retire, 8.3 percent experiencing a layoff and then not finding new employment, and 4.3 percent experiencing a layoff but finding new employment. If these shocks are also associated with early retirement, they could be important drivers of this phenomenon. The final column of Table 2 indicates that 40.1 percent of those experiencing a health shock retire early, compared to 40.7 percent for those with a spouse retiring and 61.7 percent for those who lose their jobs involuntarily and do not return to work. In other words, even though health shocks are quite common, at a first glance they have only a small impact on retirement for those experiencing them. Table 3 compares the two cohorts used in this analysis and shows that they have fairly similar experiences regarding shocks and early retirement. However, individuals in the War Baby Cohort are slightly less likely to retire early than those in the HRS Cohort and slightly more likely to have health shocks and to experience layoffs. Table 4 provides descriptive statistics on the demographics and initial characteristics of the sample for many of the variables that will be used in this analysis.

\section{Empirical Analysis}

The empirical analysis takes place in two steps. First, a probit model is estimated where the dependent variable indicates workers retired before they planned. The estimates from this first step reveal the strength of the relationship between early retirement and the shocks included in the model for those workers that experience them. Of course, this estimation is only part of determining which shocks are most responsible for early retirement - the prevalence of the shocks matters too. To incorporate both prevalence and the strength of the relationship, the second step uses the estimates from the probit to form counterfactual predictions of the share of workers that would have retired early had no one experienced shocks. The more these counterfactual predictions deviate from reality, the more important the shock in determining early retirement. 


\section{Probit Regression Analysis}

The regression analysis takes the form of a standard probit, where the dependent variable takes on a value of one if an individual retires one year or more before they planned to and a value of zero if they retire on-time (within one year) or after they planned to:

$$
y_{i}^{*}=\beta_{0}+I_{i} \beta+S_{i} \delta+\varepsilon_{i}
$$

where $y_{i}^{*}$ is a person's unobserved propensity to retire early; we observe only $y_{i}=I\left(y_{i}^{*}>0\right)$, which equals one when the index is sufficiently large that person $i$ actually retires early. $I_{i}$ are the initial conditions, and $S_{i}$ are the shocks. Positive coefficients in the vector $\beta$ would indicate that individuals with certain initial characteristics are more likely to retire early, i.e., they are worse planners; such a finding is unexpected, based on the theory of rational expectations. At the same time, other authors have found that initial conditions, including initial health, do have an impact on the probability of early retirement. ${ }^{15}$

Identification of the causal impact of shocks on the probability of early retirement requires that the unobserved component $\varepsilon_{i}$ is uncorrelated with the shocks themselves. The controls contained in $I_{i}$ are meant to lessen this possibility of correlation, but to the extent any correlation remains then the results would be biased. Given this caveat, positive $\delta$ coefficients would indicate the presence of the shock is associated with an increased probability of retiring early, but not necessarily that the shock causes the individual to retire earlier than he had planned.

\section{Counterfactual Predictions}

Using the regression estimates, the next step is to see how much lower the propensity to retire early would be if each shock did not occur. In this exercise, the following predictions are generated:

$$
\widehat{p}_{\iota}=\Phi\left(\hat{\beta}_{0}+I_{i} \hat{\beta}+\tilde{S}_{i} \hat{\delta}\right)
$$

\footnotetext{
${ }^{15}$ For example, see Munnell, Jivan, and Triest (2005).
} 
where $\widehat{p}_{\imath}$ is the predicted probability a given individual retires early, $I_{i}$ is the individual's actual initial and demographic characteristics, $\tilde{S}_{i}$ is a counterfactual set of shocks where some shocks have been set to zero even if they occurred, and $\Phi$ is the cumulative normal distribution. By setting individual or groups of shocks to zero, the average predicted probabilities can be compared to the actual predicted probabilities to quantify the shocks' importance in earlier-thanplanned retirement. This straightforward approach takes into account both the frequency of the shock in the population and the impact of the shock on those that experience it as embodied by the regression coefficients; if a shock is rare, eliminating the possibility of that shock will only have a small effect on $p_{i}$ even if the correlation between that shock and $p_{i}$ is strong.

\section{Results}

The regression results are reported in Tables 5a (all sample members) and 5b (only sample members who report an expected retirement age at their age-58 interview). Regression results are reported as marginal effects at the average of the data and are shown for three specifications: 1) shocks only; 2) adding initial conditions and demographics; and 3) adding characteristics of the new job for workers who switch jobs or find re-employment after a layoff or business closing. Unless otherwise stated, the discussion below refers to the second specification, because the interpretation of the employment shocks is most straightforward without the inclusion of the characteristics of the new job. The counterfactual predictions in Table 6 use this specification, except for the prediction for when all new employment is in "good" jobs.

\section{Probit Regression Results}

The regression results contained in Tables 5a and 5b are largely intuitive. To begin, looking at the second specification in Table 5a, individuals whose health index increases by one unit (health worsens by one condition) between their planning age and their planned retirement age are 2.2 percentage points more likely to retire early, and this correlation is statistically significant. ${ }^{16}$ Interestingly, the interaction of having a health shock with having access to health insurance outside of employment is positive and as large as the coefficient on the health shocks

\footnotetext{
${ }^{16}$ Although the objective health index was our chosen metric for health changes, we also examined changes in subjective health. In general, we found that the health index was a stronger predictor of early retirement. Indeed, when both subjective health and the objective health index were included together, only changes in the objective health index were a significant predictor of early retirement.
} 
themselves - but it is also statistically insignificant. While this result is consistent with the notion that outside options for health insurance let people respond to health shocks with retirement, it is ultimately inconclusive. Unlike most of the other initial conditions, an individual's initial health does have a significant correlation with the probability of early retirement - each additional health condition a person has at their planning age is associated with a 3.3-percentage-point increase in the probability of early retirement. Although individuals should be aware of their health when making their plans and have a younger expected retirement age, this result may stem from a misestimate of how quickly some conditions deteriorate with age.

Individuals who lose their jobs through a layoff or business closing are 27.6 percentage points more likely to retire early than other workers. But this result holds only for individuals who do not find re-employment. Switching jobs - regardless of whether the initial change occurred voluntarily - actually decreases the likelihood that workers retire earlier than planned. Workers who change employers are 6.8 percentage points less likely to retire earlier than planned. Workers who both lose their jobs in a layoff or business closing and find reemployment have a similar reduction in their probability of retiring early relative to nonchangers; the results suggest that the negative impact of involuntary job loss is undone by finding a new job.

Workers have several potential reasons for switching employers - voluntarily or not each of which could influence the probability of retiring early. The third specification in Tables 5a and 5b includes four new variables that account for how the characteristics of the new job, compared to the job held in the age-58 wave, influence early retirement. Some workers switch to more lucrative jobs; in that event (about one-half of job changes), the worker is less likely to retire early. Another reason for making a job switch is to reduce responsibility; indeed, the estimates indicate that when the new job requires fewer hours or is less stressful, the job-switcher is less likely to retire early, though the correlation between early retirement and switching to a less physical job is statistically insignificant. On the other hand, moving to a job that does not have these positive characteristics (i.e., is more hours, less money, and more stress) makes individuals much more likely to retire early. This result suggests not all mobility is a good thing - movement has to be to the kind of job that is conducive to an extended career. 
The effects of familial shocks are more muted, with two notable exceptions - the retirement of a spouse before the planned retirement date and having parents move into the home. The retirement of a spouse before the worker planned to retire is correlated with a 4.2percentage-point increase in the likelihood of retiring early. Because research has shown that spouses tend to make the retirement decision jointly (Coile 2004, Gustman and Steinmeier 2000), a high correlation between the two spouses' decisions to retire early is not surprising. Having a parent move in has a large impact on the probability of retiring early, increasing it by approximately 12.1 percent percentage points.

The results indicate that financial shocks do not have a significant impact on early retirement. This finding does not appear to be a specification issue - the result held using a variety of measures of financial shocks, including binary indicators for decreases or increases in wealth of 50 percent or more, indicators for average annual returns well above or below typical values, or simply using the largest difference in wealth reported prior to the planning date. The finding that financial shocks do not appear to induce early retirement concurs with earlier research. ${ }^{17}$

As expected, few of the initial conditions are significantly correlated with retiring early. Individuals with pensions are less likely to retire early than other individuals. Munnell, Jivan, and Triest (2005) found a similar result and hypothesized that these individuals were more accurate planners. One exception to this result is having a defined benefit or defined contribution pension plan at one's current job - both make it significantly less likely to retire earlier-than-planned. This result may be due to better work conditions or the desire to continue accruing benefits, especially in defined benefit pensions where accruals are often back-loaded. Similarly, more educated workers are less likely than high school dropouts to retire early. Otherwise, most of the demographic variables and static variables as of the planning age are statistically insignificant.

\footnotetext{
${ }^{17}$ Gustman and Steinmeier (2002) find that the stock market bubble of the late 1990s decreased the planned retirement age by about 3 months; the popping of that bubble wiped out the retirement age claim, but had no lasting effects. Estimates from Bosworth and Burtless (2010) suggest that a one standard deviation (more than 10 percentage points over three years) decrease in asset returns would increase labor force participation for those age 55 to 59 by only 0.2 to 0.4 percentage points. Other studies find no statistically significant relationship between stock market indices and retirement probabilities (Hurd and Reti 2003; Hurd, Reti, and Rohwedder 2009; Coile and Levine 2006; Goda, Shoven, and Slavov 2010). Even in the Great Recession, McFall (2011) and Gustman, Steinmeier, and Tabatabai (2010) project only a small increase in the retirement age.
} 
One variable of interest in Table 5a is the indicator for individuals who said they planned to never retire during their age-58 interview. The variable is not statistically significant, suggesting that people who initially say they never plan to retire but later do make plans reach their goal as often as others. However, to ensure these individuals do not unduly impact the results, Table 5b reports results that exclude them. On the whole, the results from Tables 5a and 5b are markedly similar. The only differences that arise from excluding people who initially did not plan on retiring are weaker levels of significance on some variables in later stages of the specification. For example, while having a spouse retire before the planned retirement wave is significant at the 10-percent level when including people who claim to never retire, that variable loses its significance after controlling for initial conditions in the specification that excludes them. This result is likely simply the consequence of having a smaller sample size.

\section{Counterfactual Predictions}

The counterfactual predictions in Table 6 use the regression results to estimate the share of individuals that would retire early if various shocks did not occur. The actual data indicate that 37.0 percent of individuals retire earlier than planned. The variable with the largest reduction relative to this benchmark is the most important factor associated with early retirement.

The first counterfactual presents the case where everyone maintains their initial health status as of the time they made their retirement plans - no one has a health shock. Under this counterfactual, the share of individuals retiring early would be 35.4 percent, a reduction of 1.6 percentage points from the benchmark. Initial health also seems to play a large role in early retirement, a result that holds consistently in other studies. ${ }^{18}$ If all individuals made their retirement plans with no negative health conditions and they experienced no health shocks, then the share of individuals retiring early would be 32.2 percent, a larger reduction of 4.8 percentage points from the benchmark.

The regression results indicate that workers experiencing health shocks are significantly more likely to retire early than others, but the effect does not differ significantly for people with access to RHI versus those without. Despite this fact, the recent changes in the provision of health insurance justify a counterfactual estimate of early retirement if everyone is assumed to have health insurance outside of employment. This counterfactual is a simple simulation of the

\footnotetext{
${ }^{18}$ For example in Munnell, Jivan, and Triest (2005).
} 
ACA, whereby people leaving employment, even under age 65, would have access to insurance through commercial marketplaces, Medicaid, or increased employer coverage. Under this assumption, the results show that early retirement increases by 0.4 percentage points.

Involuntary job loss, either through layoff or business closing, is another reason people may retire before they planned to. If no worker lost their job involuntarily between their planning age and planned retirement age, then only 35.0 percent of individuals would retire early, a reduction of 1.9 percentage points relative to the benchmark. If everyone simply maintained their same employer from their planning age to retirement - no involuntary job losses, but also no voluntary switches - the percentage of individuals expected to retire early increases by less than 0.1 percentage points. This increase reflects the dual role of job instability - losing a job is damaging to one’s retirement plans, but switching jobs makes workers more successful in reaching their retirement plans. Another interesting counterfactual is to see how much early retirement would be reduced if everyone who switched jobs moved to a "better" job with higher wages, less stress, fewer hours, and less physicality (whether or not that job was preceded by a job loss). The results show that, relative to the real world where some people move to worse jobs, early retirement is reduced by 2.9 percentage points.

Familial changes also play a role in early retirement. In the regression analysis, the biggest factor was having a parent move in, followed by a spouse's retirement prior to the planned retirement age. However, as Table 2 shows, having parents move in happens to less than 2 percent of the sample, whereas almost 20 percent of the sample has a spouse retire before the planned date. As Table 6 shows, the end result is that even though the coefficient on having a parent move in is larger than having a spouse retire, the latter is more important in driving early retirement in the population. The coefficient on having a spouse who experiences failing health was also large in magnitude, though statistically insignificant. The other shocks considered, namely a change in marital status and having a resident child, were insignificant. If all of these shocks (even the insignificant ones) were assumed to not occur, then 35.4 percent of individuals would retire early, a reduction of 1.6 percentage points from the benchmark. If instead we only assumed that spouses always retire at the exact same time as the worker, then 36.2 percent of individuals would retire early. Although the reduction is smaller than for health, familial changes clearly have a substantial impact on early retirement. 
If workers' financial wealth remains unchanged, the probability of early retirement falls by 1.6 percentage points relative to the benchmark. Although financial shocks occur relatively frequently and are not found to be significant in our regression results, they are also not trivial in their ability to alter the probability of retiring before expectation.

The final experiment is to assume that none of the shocks occur. In this experiment, only 27.1 percent of workers retire early, a reduction of 9.9 percentage points from the baseline. While this is a large reduction, it also illustrates that many individuals retire before they plan without a shock intervening. This result - that even a comprehensive model of factors that influence retirement accounts for about one-quarter of earlier-than-planned retirement - suggests that idiosyncratic, hard-to-measure factors have more influence, such as job satisfaction, outside employment prospects, or the attractiveness of leisure time.

\section{Conclusion}

This paper explores whether health, employment, family, or finances are most likely to be associated with earlier-than-planned retirement. The results suggest health is most important, followed by involuntary job loss and familial shocks such as a spouse's retirement or having a parent move in. Financial shocks appear to play only a small role. At the same time, these factors explain about a quarter percent of all early retirements, suggesting that other factors play a role in causing people to inaccurately forecast their retirement date even as late as age 58.

Looking forward, the results in this paper have several implications. First, should health improve in the future, then people should be more likely to achieve their retirement goals, ultimately working longer. The results in this paper suggest that the response to health shocks is slightly higher if retiree health insurance is available, but the estimate is statistically insignificant and more research is needed to establish whether the ACA will induce workers whose health deteriorates to retire earlier. Increasing job instability will likely have offsetting effects. Increasing job-to-job mobility will be expected to reduce earlier-than-planned retirement as long as the job movements continue to be toward better jobs. But should layoffs become more common, early retirement may increase since most of these laid off workers (about 66 percent) do not find new work. On the familial side, because more parents of Baby Boomers are living to the age range where care is needed, having parents move in could also drive early retirement in the future. In other words, the paper suggests that the trends in earlier-than-planned retirement in 
the future are unclear and could move toward more or less early retirement, and the trends will depend on which types of shocks become more prevalent. Putting all these factors together in a model provides valuable guidance to researchers and policymakers to determine what to monitor. 


\section{References}

Anderson, Kathryn H., Richard V. Burkhauser, and Joseph F. Quinn. 1986. “Do Retirement Dreams Come True? The Effect of Unanticipated Events on Retirement Plans.” Industrial and Labor Relations Review 39(4): 518-526.

Benitez-Silva, Hugo and Debra S. Dwyer. 2005. “The Rationality of Retirement Expectations and the Role of New Information.” The Review of Economics and Statistics 87(3): 587592.

Bosworth, Barry P. and Gary Burtless. 2010. "Recessions, Wealth Destruction and the Timing of Retirement.” Working Paper 2010-22. Chestnut Hill, MA: Center for Retirement Research at Boston College.

Coile, Courtney C. 2004. “Retirement Incentives and Couples’ Retirement Decisions.” Topics in Economic Analysis \& Policy 4(1): article 17.

Coile, Courtney C. and Phillip B. Levine. 2006. "Bulls, Bears, and Retirement Behavior.” Industrial and Labor Relations Review 59(3): 408-429.

Congressional Budget Office. 2014. “The Budget and Economic Outlook: 2014 to 2024.” February 2014 update. Washington, DC: Congressional Budget Office.

Disney, Richard and Sarah Tanner. 1999. "What Can We Learn From Retirement Expectations Data?” IFS Working Papers No W99/17. London, UK: Institute for Financial Studies.

Dwyer, Debra S. and Jianting Hu. 2000. "Retirement Expectations and Realizations: The Role of Health Shocks and Economic Factors.” In Forecasting Retirement Needs and Retirement Wealth, edited by Olivia S. Mitchell, P. Brett Hammond, and Anna M. Rappaport, 274-287. Philadelphia, PA: University of Pennsylvania Press.

Dwyer, Debra S. and Olivia S. Mitchell. 1999. "Health Problems as Determinants of Retirement: Are Self-Rated Measures Endogenous?” Journal of Health Economics 18(1999): 173193.

Employee Benefit Research Institute. 2014. "Fact Sheet: Changing Expectations about Retirement.” Working Paper. Washington, DC: Employee Benefit Research Institute.

Goda, Gopi Shah, John B. Shoven, and Sita Nataraj Slavov. 2010. “Does Stock Market Performance Influence Retirement Intentions?” Working Paper 16211. Cambridge, MA: National Bureau of Economic Research.

Gustman, Alan L. and Thomas L. Steinmeier. 2000. "Retirement in a Family Context: A Structural Model,” Journal of Labor Economics 18(3): 503-545.

Gustman, Alan L. and Thomas L. Steinmeier. 2002. "Retirement and the Stock Market Bubble.” Working Paper 9404. Cambridge, MA: National Bureau of Economic Research. 
Gustman, Alan L., Thomas L. Steinmeier, and Nahid Tabatabai. 2010. "What the Stock Market Decline Means for the Financial Security and Retirement Choices of the Near-Retirement Population.” Journal of Economic Perspectives 24(1): 161-182.

Honig, Marjorie. 1996. “Retirement Expectations: Differences by Race, Ethnicity, and Gender.” The Gerontologist Society of America 36(3): 373-382.

Hurd, Michael and Monika Reti. 2003. “The Effects of Large Capital Gains on Work and Consumption: Evidence from Four Waves of the HRS.” Labor and Population Program Working Paper 03-14. Santa Monica, CA: RAND.

Hurd, Michael D., Monika Reti, and Susann Rohwedder. 2009. “The Effect of Large Capital Gains or Losses on Retirement," in Developments in the Economics of Aging, edited by David A. Wise, 127-164. Chicago, IL: University of Chicago Press.

McFall, Brooke Helppie. 2011. "Crash and Wait? The Impact of the Great Recession on the Retirement Plans of Older Americans.” American Economic Review Papers and Proceedings 101(3): 40-44.

McGarry, Kathleen. 2004. “Do Changes in Health Affect Retirement Expectations?” The Journal of Human Resources 39(3): 624-648.

Munnell, Alicia H., Alex Golub-Sass, and Mauricio Soto. 2008. "Will People Be Healthy Enough to Work Longer?” Working Paper 2008-11. Chestnut Hill, MA: Center for Retirement Research at Boston College.

Munnell, Alicia H., Robert K. Triest, and Natalia Jivan. 2004. “How Do Pensions Affect Expected and Actual Retirement Ages?” Working Paper 2004-1. Chestnut Hill, MA: Center for Retirement Research at Boston College.

Örestig, Johan, Mattias Strandh, and Mikael Stattin. 2013. “A Wish Come True? A Longitudinal Analysis of the Relationship between Retirement Preferences and the Timing of Retirement.” Journal of Population Ageing 6(1-2): 99-118. 
Table 1. Distribution of Reporting Ages of Expected Retirement Age

\begin{tabular}{|c|c|c|c|}
\hline $\begin{array}{l}\text { Age closest to } 58 \text { with an } \\
\text { expected retirement age reported }\end{array}$ & $\begin{array}{l}\text { Share of age within } \\
\text { the sample }\end{array}$ & $\begin{array}{l}\text { Avg. expected } \\
\text { retirement age }\end{array}$ & $\begin{array}{c}\text { Share retiring before } \\
\text { planned date }\end{array}$ \\
\hline 55 & $2.4 \%$ & 63.7 & $48.9 \%$ \\
\hline 56 & 9.8 & 63.4 & 38.8 \\
\hline 57 & 26.9 & 63.3 & 35.8 \\
\hline 58 & 25.1 & 63.4 & 33.4 \\
\hline 59 & 12.3 & 63.9 & 34.8 \\
\hline 60 & 9.7 & 64.2 & 34.9 \\
\hline 61 & 7.1 & 64.7 & 34.9 \\
\hline 62 & 1.6 & 66.0 & 36.7 \\
\hline 63 & 1.3 & 66.6 & 30.0 \\
\hline 64 & 1.0 & 67.4 & 50.0 \\
\hline 65 & 0.6 & 68.6 & 22.7 \\
\hline 66 & 0.9 & 69.2 & 30.3 \\
\hline 67 & 0.5 & 69.8 & 19.0 \\
\hline 68 & 0.4 & 71.8 & 25.0 \\
\hline 69 & 0.3 & 71.3 & 20.0 \\
\hline 70 & 0.2 & 73.1 & 28.6 \\
\hline
\end{tabular}

Source: Authors' calculations from the Health and Retirement Study, 1992-2012 waves. 
Table 2. Descriptive Statistics of Shocks Before Planned Retirement \& After Age-58 Wave

\begin{tabular}{|c|c|c|}
\hline Shock & Share & Retiring early \\
\hline Sample, regardless of shock & --- \% & $37.1 \%$ \\
\hline Health Index difference is positive & 39.9 & 40.1 \\
\hline Resident child leaves home & 16.4 & 35.8 \\
\hline Partially retires & 20.3 & 32.5 \\
\hline Spouse retires & 19.7 & 40.7 \\
\hline Spouse continues to work & 44.9 & 35.1 \\
\hline Spouse experiences fair or poor health shock & 7.9 & 38.0 \\
\hline Different employer from age- 58 wave, no job loss & 8.1 & 28.3 \\
\hline New job has higher earnings & 48.7 & 27.1 \\
\hline New job requires less hours & 57.2 & 18.1 \\
\hline New job is less stressful & 36.5 & 15.5 \\
\hline New job is less physical & 34.0 & 20.4 \\
\hline Involuntary job loss, no new job & 8.3 & 61.7 \\
\hline Involuntary job loss, new job & 4.3 & 28.2 \\
\hline New job has higher earnings & 45.9 & 19.2 \\
\hline New job requires less hours & 42.4 & 9.7 \\
\hline New job is less stressful & 31.8 & 7.4 \\
\hline New job is less physical & 34.7 & 11.9 \\
\hline Wealth declines by at least $50 \%$ & 37.0 & 38.6 \\
\hline Wealth increases by at least $50 \%$ & 49.9 & 37.2 \\
\hline Marital status change & 19.4 & 40.1 \\
\hline Parent moves in & 1.4 & 45.5 \\
\hline Starts taking care of parent & 12.1 & 35.3 \\
\hline Becomes a grandparent & 8.2 & 34.5 \\
\hline Number of observations & 3,943 & 3,943 \\
\hline
\end{tabular}

Source: Authors' calculations from the Health and Retirement Study, 1992-2012 waves. 
Table 3. Descriptive Statistics of Shocks Before Planned Retirement \& After Age-58 Wave by Cohort

\begin{tabular}{|c|c|c|c|c|}
\hline \multirow{2}{*}{ Shock } & \multicolumn{2}{|c|}{ HRS cohort } & \multicolumn{2}{|c|}{ War baby cohort } \\
\hline & Share & Retiring early & Share & Retiring early \\
\hline Sample, regardless of shock & $---\%$ & $37.4 \%$ & $---\%$ & $35.5 \%$ \\
\hline Health Index difference is positive & 39.3 & 40.1 & 43.1 & 39.9 \\
\hline Resident child leaves home & 17.3 & 35.9 & 12.0 & 35.0 \\
\hline Partially retires & 21.3 & 32.5 & 15.9 & 33.0 \\
\hline Spouse retires & 19.0 & 42.2 & 23.4 & 34.6 \\
\hline Spouse continues to work & 44.4 & 34.9 & 47.6 & 36.2 \\
\hline Spouse experiences fair or poor health shock & 7.8 & 38.9 & 8.4 & 36.2 \\
\hline Different employer from age-58 wave, no job loss & 7.8 & 28.9 & 9.3 & 25.8 \\
\hline New job has higher earnings & 47.3 & 28.1 & 54.8 & 23.5 \\
\hline New job requires less hours & 62.1 & 20.1 & 37.1 & 4.3 \\
\hline New job is less stressful & 35.9 & 17.4 & 38.7 & 8.3 \\
\hline New job is less physical & 37.1 & 21.1 & 21.0 & 15.4 \\
\hline Involuntary job loss, no new job & 8.0 & 61.8 & 9.6 & 60.9 \\
\hline Different employer after involuntary job loss & 4.4 & 27.6 & 3.7 & 32.0 \\
\hline New job has higher earnings & 46.2 & 20.9 & 44.0 & 9.1 \\
\hline New job requires less hours & 40.7 & 6.8 & 52.0 & 23.1 \\
\hline New job is less stressful & 32.4 & 6.4 & 28.0 & 14.3 \\
\hline New job is less physical & 33.8 & 10.2 & 40.0 & 20.0 \\
\hline Wealth declines by at least $50 \%$ & 36.4 & 39.2 & 40.3 & 35.7 \\
\hline Wealth increases by at least $50 \%$ & 50.9 & 37.5 & 44.9 & 36.0 \\
\hline Marital status change & 20.6 & 39.8 & 13.3 & 42.7 \\
\hline Parent moves in & 1.3 & 45.5 & 1.6 & 45.5 \\
\hline Starts taking care of parent & 12.6 & 34.3 & 9.7 & 41.5 \\
\hline Becomes a grandparent & 8.5 & 35.0 & 7.2 & 31.3 \\
\hline Number of observations & 3,275 & 3,275 & 668 & 668 \\
\hline
\end{tabular}

Source: Authors' calculations from the Health and Retirement Study, 1992-2012 waves. 
Table 4. Descriptive Statistics of Initial Age-58 Conditions

\begin{tabular}{lc}
\hline Initial condition & Mean \\
\hline At least two health conditions & $26.3 \%$ \\
Spouse is in fair or poor health & 13.7 \\
Self-employed & 10.3 \\
Job requires physical exertion & 63.6 \\
Job is stressful & 17.3 \\
White collar & 73.2 \\
Health insurance coverage & 66.0 \\
Retiree health insurance coverage & 47.4 \\
Previous DB & 34.8 \\
Current DB & 38.3 \\
Current DC & 33.5 \\
Current earnings & $\$ 43,533$ \\
Pension income & $\$ 1,206$ \\
Financial wealth & $\$ 125,816$ \\
Married & $75.6 \%$ \\
Presence of resident child & 32.4 \\
Parent lives with respondent & 2.6 \\
Respondent cares for parent & 9.6 \\
Respondent is a grandparent & 74.6 \\
Spouse is working & 48.5 \\
Less than high school & 19.4 \\
College & 42.5 \\
Female & 52.8 \\
\hline Number of observations & 3,831 \\
\hline
\end{tabular}

Source: Authors' calculations from the Health and Retirement Study, 1992-2012 waves. 
Table 5a. Marginal Effect on Probability of Retiring Before Plan, Including "Never"

\begin{tabular}{|c|c|c|c|}
\hline Variables & Shocks only & $\begin{array}{l}\text { Shocks, initial } \\
\text { conditions } \\
+ \text { demographics }\end{array}$ & $\begin{array}{l}\text { Shocks, initial } \\
\text { conditions, } \\
\text { demographics } \\
+ \text { new job }\end{array}$ \\
\hline \multicolumn{4}{|l|}{ Health-related shock variables } \\
\hline Health index difference & $\begin{array}{l}0.020^{* *} \\
(0.010)\end{array}$ & $\begin{array}{l}0.022^{* *} \\
(0.010)\end{array}$ & $\begin{array}{l}0.021 \text { ** } \\
(0.010)\end{array}$ \\
\hline RHI coverage $x$ health index difference & $\begin{array}{r}0.013 \\
(0.014)\end{array}$ & $\begin{array}{r}0.025 \\
(0.016)\end{array}$ & $\begin{array}{r}0.023 \\
(0.016)\end{array}$ \\
\hline \multicolumn{4}{|l|}{ Job-related shock variables } \\
\hline Partially retired & $\begin{array}{l}-0.058^{* * *} \\
(0.020)\end{array}$ & $\begin{array}{l}-0.073^{* * *} \\
(0.020)\end{array}$ & $\begin{array}{l}-0.080^{* * *} \\
(0.020)\end{array}$ \\
\hline Different employer, no involuntary job loss & $\begin{array}{l}-0.064^{* *} \\
(0.029)\end{array}$ & $\begin{array}{l}-0.068 * * \\
(0.030)\end{array}$ & $\begin{array}{l}0.246^{* * *} \\
(0.056)\end{array}$ \\
\hline Involuntary job loss, no new job & $\begin{array}{l}0.264^{* * *} \\
(0.029)\end{array}$ & $\begin{array}{l}0.276^{* * *} \\
(0.030)\end{array}$ & $\begin{array}{l}0.277^{* * * *} \\
(0.030)\end{array}$ \\
\hline Different employer after involuntary job loss & $\begin{array}{l}-0.071^{*} \\
(0.037)\end{array}$ & $\begin{array}{l}-0.066^{*} \\
(0.040)\end{array}$ & $\begin{array}{l}0.180^{* * *} \\
(0.060)\end{array}$ \\
\hline New job has higher earnings & $\begin{array}{l}-- \\
--\end{array}$ & $\begin{array}{l}-- \\
--\end{array}$ & $\begin{array}{l}-0.156^{* * *} \\
(0.042)\end{array}$ \\
\hline New job requires fewer hours & $\begin{array}{l}-- \\
--\end{array}$ & $\begin{array}{l}-- \\
--\end{array}$ & $\begin{array}{l}-0.214^{\text {*** }} \\
(0.034)\end{array}$ \\
\hline New job is less stressful & $\begin{array}{l}-- \\
--\end{array}$ & $\begin{array}{l}-- \\
--\end{array}$ & $\begin{array}{l}-0.183^{* * *} \\
(0.042)\end{array}$ \\
\hline New job is less physical demanding & $\begin{array}{l}-- \\
--\end{array}$ & $\begin{array}{l}-- \\
--\end{array}$ & $\begin{array}{r}-0.063 \\
(0.052)\end{array}$ \\
\hline Family-related shock variables & & & \\
\hline Marital status change & $\begin{array}{c}0.038^{*} \\
(0.021)\end{array}$ & $\begin{array}{r}0.020 \\
(0.022)\end{array}$ & $\begin{array}{r}0.015 \\
(0.022)\end{array}$ \\
\hline Resident child leaves home & $\begin{array}{r}-0.009 \\
(0.021)\end{array}$ & $\begin{array}{r}0.011 \\
(0.029)\end{array}$ & $\begin{array}{r}0.015 \\
(0.029)\end{array}$ \\
\hline Spouse experiences fair/poor health shock & $\begin{array}{r}0.014 \\
(0.030)\end{array}$ & $\begin{array}{r}0.024 \\
(0.031)\end{array}$ & $\begin{array}{r}0.019 \\
(0.031)\end{array}$ \\
\hline Spouse continues working & $\begin{array}{r}-0.024 \\
(0.016)\end{array}$ & $\begin{array}{l}-0.049^{*} \\
(0.026)\end{array}$ & $\begin{array}{c}-0.046^{*} \\
(0.026)\end{array}$ \\
\hline Spouse retires & $\begin{array}{l}0.059 * * * \\
(0.020)\end{array}$ & $\begin{array}{c}0.042^{*} \\
(0.022)\end{array}$ & $\begin{array}{l}0.044^{* *} \\
(0.022)\end{array}$ \\
\hline Parent moves in & $\begin{array}{r}0.094 \\
(0.071)\end{array}$ & $\begin{array}{c}0.121^{*} \\
(0.074)\end{array}$ & $\begin{array}{c}0.119 * \\
(0.073)\end{array}$ \\
\hline Starts taking care of parent & $\begin{array}{r}-0.020 \\
(0.024)\end{array}$ & $\begin{array}{r}-0.020 \\
(0.025)\end{array}$ & $\begin{array}{r}-0.023 \\
(0.025)\end{array}$ \\
\hline Becomes a grandparent & $\begin{array}{r}-0.014 \\
(0.028)\end{array}$ & $\begin{array}{r}0.016 \\
(0.035)\end{array}$ & $\begin{array}{r}0.008 \\
(0.035)\end{array}$ \\
\hline
\end{tabular}

-cont'd- 


\begin{tabular}{|c|c|c|c|}
\hline Variables & Shocks only & $\begin{array}{l}\text { Shocks, initial } \\
\text { conditions } \\
+ \text { demographics }\end{array}$ & $\begin{array}{l}\text { Shocks, initial } \\
\text { conditions, } \\
\text { demographics } \\
\text { + new job }\end{array}$ \\
\hline \multicolumn{4}{|l|}{ Wealth-related shock variables } \\
\hline \multirow[t]{2}{*}{ Financial gain of at least 50\% } & 0.019 & 0.015 & 0.013 \\
\hline & $(0.020)$ & $(0.021)$ & $(0.021)$ \\
\hline \multirow[t]{2}{*}{ Financial loss of at least $50 \%$} & 0.028 & 0.026 & 0.022 \\
\hline & $(0.020)$ & $(0.021)$ & $(0.022)$ \\
\hline \multicolumn{4}{|l|}{ Health-related initial conditions } \\
\hline \multirow[t]{2}{*}{ Health index } & -- & $0.033 * * *$ & $0.033 * * *$ \\
\hline & -- & $(0.008)$ & $(0.008)$ \\
\hline \multicolumn{4}{|l|}{ Job-related initial conditions } \\
\hline \multirow[t]{2}{*}{ Self-employed } & -- & -0.028 & -0.028 \\
\hline & -- & $(0.029)$ & $(0.029)$ \\
\hline \multirow[t]{2}{*}{ Job is physically demanding } & -- & -0.007 & -0.009 \\
\hline & -- & $(0.017)$ & $(0.017)$ \\
\hline \multirow[t]{2}{*}{ Job is stressful } & -- & 0.005 & -0.005 \\
\hline & -- & $(0.022)$ & $(0.022)$ \\
\hline \multirow[t]{2}{*}{ White collar } & -- & 0.013 & 0.012 \\
\hline & -- & $(0.021)$ & $(0.021)$ \\
\hline \multirow[t]{2}{*}{ Employer-covered health insurance } & -- & -0.011 & -0.004 \\
\hline & -- & $(0.025)$ & $(0.025)$ \\
\hline \multirow[t]{2}{*}{ RHI coverage } & -- & 0.008 & 0.010 \\
\hline & -- & $(0.023)$ & $(0.023)$ \\
\hline \multirow[t]{2}{*}{ Previous DB } & -- & 0.017 & 0.011 \\
\hline & -- & $(0.023)$ & $(0.023)$ \\
\hline \multirow[t]{2}{*}{ DB } & -- & $-0.053 * *$ & $-0.053 * *$ \\
\hline & -- & $(0.023)$ & $(0.024)$ \\
\hline \multirow[t]{2}{*}{ DC } & -- & $-0.048 * * *$ & $-0.050 * * *$ \\
\hline & -- & $(0.018)$ & $(0.018)$ \\
\hline \multicolumn{4}{|l|}{ Family-related initial conditions } \\
\hline \multirow[t]{2}{*}{ Married } & -- & -0.037 & -0.038 \\
\hline & -- & $(0.028)$ & $(0.028)$ \\
\hline \multirow[t]{2}{*}{ Presence of resident child } & -- & -0.019 & -0.019 \\
\hline & -- & $(0.023)$ & $(0.023)$ \\
\hline \multirow[t]{2}{*}{ Spouse is in fair/poor health } & -- & 0.016 & 0.015 \\
\hline & -- & $(0.026)$ & $(0.026)$ \\
\hline \multirow[t]{2}{*}{ Spouse's current earnings } & -- & 0.000 & 0.000 \\
\hline & -- & $(0.000)$ & $(0.000)$ \\
\hline \multirow[t]{2}{*}{ Spouse provides HI coverage } & -- & 0.021 & 0.021 \\
\hline & -- & $(0.025)$ & $(0.025)$ \\
\hline \multirow[t]{2}{*}{ Spouse is working } & -- & 0.023 & 0.023 \\
\hline & -- & $(0.028)$ & $(0.028)$ \\
\hline
\end{tabular}

-cont'd- 


\begin{tabular}{|c|c|c|c|}
\hline Variables & Shocks only & $\begin{array}{l}\text { Shocks, initial } \\
\text { conditions } \\
\text { + demographics }\end{array}$ & $\begin{array}{l}\text { Shocks, initial } \\
\text { conditions, } \\
\text { demographics } \\
+ \text { new job }\end{array}$ \\
\hline \multirow[t]{2}{*}{ Presence of resident parent } & -- & 0.034 & 0.034 \\
\hline & -- & $(0.054)$ & $(0.053)$ \\
\hline \multirow[t]{2}{*}{ Cares for parent } & -- & 0.017 & 0.014 \\
\hline & -- & $(0.030)$ & $(0.030)$ \\
\hline \multirow[t]{2}{*}{ Is a grandparent } & -- & 0.009 & 0.003 \\
\hline & -- & $(0.022)$ & $(0.022)$ \\
\hline \multicolumn{4}{|c|}{ Wealth-related initial conditions } \\
\hline \multirow[t]{2}{*}{ Current earnings } & -- & -0.000 & -0.000 \\
\hline & -- & $(0.000)$ & $(0.000)$ \\
\hline \multirow[t]{2}{*}{ Pension income } & -- & 0.002 & 0.002 \\
\hline & -- & $(0.001)$ & $(0.001)$ \\
\hline \multirow[t]{2}{*}{ Financial wealth } & -- & -0.000 & -0.000 \\
\hline & -- & $(0.000)$ & $(0.000)$ \\
\hline \multicolumn{4}{|l|}{ Miscellaneous controls } \\
\hline \multirow[t]{2}{*}{ Says "never will retire" } & $0.045^{*}$ & $0.069 *$ & $0.068 *$ \\
\hline & $(0.026)$ & $(0.036)$ & $(0.037)$ \\
\hline \multirow[t]{2}{*}{ War baby cohort } & -0.031 & 0.012 & 0.010 \\
\hline & $(0.021)$ & $(0.039)$ & $(0.039)$ \\
\hline Time controls? & No & Yes & Yes \\
\hline Demographic controls? & No & Yes & Yes \\
\hline Observations & 3,943 & 3,831 & 3,831 \\
\hline
\end{tabular}

Note: * $\mathrm{p}<0.05,{ }^{* *} \mathrm{p}<0.01,{ }^{* * *} \mathrm{p}<0.001$.

Source: Authors' estimates from the Health and Retirement Study, 1992-2012 waves. 
Table 5b. Marginal Effect on Probability of Retiring Before Plan, Excluding "Never"

\begin{tabular}{|c|c|c|c|}
\hline Variables & Shocks only & $\begin{array}{l}\text { Shocks, initial } \\
\text { conditions } \\
\text { + demographics }\end{array}$ & $\begin{array}{l}\text { Shocks, initial } \\
\text { conditions, } \\
\text { demographics } \\
\text { + new job }\end{array}$ \\
\hline \multicolumn{4}{|l|}{ Health-related shock variables } \\
\hline \multirow[t]{2}{*}{ Health index difference } & $0.021 * *$ & $0.021 * *$ & $0.021 *$ \\
\hline & $(0.010)$ & $(0.011)$ & $(0.011)$ \\
\hline \multirow[t]{2}{*}{ RHI coverage $x$ health index difference } & 0.015 & $0.028 *$ & 0.027 \\
\hline & $(0.014)$ & $(0.016)$ & $(0.016)$ \\
\hline \multicolumn{4}{|l|}{ Job-related shock variables } \\
\hline \multirow[t]{2}{*}{ Partially retired } & $-0.050 * *$ & $-0.062 * * *$ & $-0.068 * * *$ \\
\hline & $(0.021)$ & $(0.021)$ & $(0.022)$ \\
\hline \multirow[t]{2}{*}{ Different employer, no involuntary job loss } & $-0.058 *$ & $-0.056 *$ & $0.261 * * *$ \\
\hline & $(0.030)$ & $(0.031)$ & $(0.058)$ \\
\hline \multirow[t]{2}{*}{ Involuntary job loss, no new job } & $0.254 * * *$ & $0.264 * * *$ & $0.266^{* * *}$ \\
\hline & $(0.031)$ & $(0.032)$ & $(0.032)$ \\
\hline \multirow[t]{2}{*}{ Different employer after involuntary job loss } & $-0.076^{* *}$ & -0.065 & $0.189 * * *$ \\
\hline & $(0.038)$ & $(0.041)$ & $(0.063)$ \\
\hline \multirow[t]{2}{*}{ New job has higher earnings } & -- & - & $-0.147 * * *$ \\
\hline & -- & -- & $(0.044)$ \\
\hline \multirow[t]{2}{*}{ New job requires fewer hours } & -- & -- & $-0.223 * * *$ \\
\hline & -- & -- & $(0.034)$ \\
\hline \multirow[t]{2}{*}{ New job is less stressful } & -- & -- & $-0.171 * * *$ \\
\hline & -- & -- & $(0.044)$ \\
\hline \multirow[t]{2}{*}{ New job is less physical demanding } & -- & -- & -0.076 \\
\hline & -- & -- & $(0.052)$ \\
\hline \multicolumn{4}{|l|}{ Family-related shock variables } \\
\hline \multirow[t]{2}{*}{ Marital status change } & 0.033 & 0.021 & 0.016 \\
\hline & $(0.022)$ & $(0.023)$ & $(0.023)$ \\
\hline \multirow[t]{2}{*}{ Resident child leaves home } & -0.004 & 0.011 & 0.015 \\
\hline & $(0.022)$ & $(0.030)$ & $(0.030)$ \\
\hline \multirow[t]{2}{*}{ Spouse experiences fair/poor health shock } & 0.013 & 0.020 & 0.015 \\
\hline & $(0.030)$ & $(0.032)$ & $(0.032)$ \\
\hline \multirow[t]{2}{*}{ Spouse continues working } & -0.021 & $-0.053 * *$ & $-0.049 *$ \\
\hline & $(0.017)$ & $(0.027)$ & $(0.027)$ \\
\hline \multirow[t]{2}{*}{ Spouse retires } & $0.047 * *$ & 0.029 & 0.031 \\
\hline & $(0.021)$ & $(0.023)$ & $(0.023)$ \\
\hline \multirow[t]{2}{*}{ Parent moves in } & 0.076 & 0.107 & 0.104 \\
\hline & $(0.073)$ & $(0.077)$ & $(0.076)$ \\
\hline \multirow[t]{2}{*}{ Starts taking care of parent } & -0.023 & -0.022 & -0.027 \\
\hline & $(0.024)$ & $(0.026)$ & $(0.026)$ \\
\hline \multirow[t]{2}{*}{ Becomes a grandparent } & -0.010 & 0.007 & -0.000 \\
\hline & $(0.029)$ & $(0.036)$ & $(0.035)$ \\
\hline
\end{tabular}

-cont'd- 


\begin{tabular}{|c|c|c|c|}
\hline Variables & Shocks only & $\begin{array}{l}\text { Shocks, initial } \\
\text { conditions } \\
+ \text { demographics }\end{array}$ & $\begin{array}{l}\text { Shocks, initial } \\
\text { conditions, } \\
\text { demographics } \\
+ \text { new job } \\
\end{array}$ \\
\hline \multicolumn{4}{|l|}{ Wealth-related shock variables } \\
\hline \multirow[t]{2}{*}{ Financial gain of at least 50\% } & -0.006 & -0.014 & -0.017 \\
\hline & $(0.021)$ & $(0.022)$ & $(0.022)$ \\
\hline \multirow[t]{2}{*}{ Financial loss of at least 50\% } & 0.008 & -0.000 & -0.003 \\
\hline & $(0.021)$ & $(0.023)$ & $(0.023)$ \\
\hline \multicolumn{4}{|l|}{ Health-related initial conditions } \\
\hline \multirow[t]{2}{*}{ Health index } & -- & $0.036 * * *$ & $0.037 * * *$ \\
\hline & -- & $(0.008)$ & $(0.008)$ \\
\hline \multicolumn{4}{|l|}{ Job-related initial conditions } \\
\hline \multirow[t]{2}{*}{ Self-employed } & -- & -0.034 & -0.034 \\
\hline & -- & $(0.031)$ & $(0.031)$ \\
\hline \multirow[t]{2}{*}{ Job is physically demanding } & -- & -0.006 & -0.008 \\
\hline & -- & $(0.018)$ & $(0.018)$ \\
\hline \multirow[t]{2}{*}{ Job is stressful } & -- & 0.004 & -0.007 \\
\hline & -- & $(0.023)$ & $(0.023)$ \\
\hline \multirow[t]{2}{*}{ White collar } & -- & 0.017 & 0.018 \\
\hline & -- & $(0.022)$ & $(0.022)$ \\
\hline \multirow[t]{2}{*}{ Employer-covered health insurance } & -- & 0.005 & 0.012 \\
\hline & -- & $(0.027)$ & $(0.027)$ \\
\hline \multirow[t]{2}{*}{ RHI coverage } & -- & -0.011 & -0.011 \\
\hline & -- & $(0.024)$ & $(0.024)$ \\
\hline \multirow[t]{2}{*}{ Previous DB } & -- & 0.006 & -0.002 \\
\hline & -- & $(0.025)$ & $(0.025)$ \\
\hline \multirow[t]{2}{*}{ DB } & -- & -0.041 & -0.038 \\
\hline & -- & $(0.025)$ & $(0.026)$ \\
\hline \multirow[t]{2}{*}{ DC } & -- & $-0.045 * *$ & $-0.047 * *$ \\
\hline & -- & $(0.019)$ & $(0.019)$ \\
\hline \multicolumn{4}{|l|}{ Family-related initial conditions } \\
\hline \multirow[t]{2}{*}{ Married } & -- & -0.011 & -0.014 \\
\hline & -- & $(0.029)$ & $(0.029)$ \\
\hline \multirow[t]{2}{*}{ Presence of resident child } & -- & -0.015 & -0.015 \\
\hline & -- & $(0.024)$ & $(0.024)$ \\
\hline \multirow[t]{2}{*}{ Spouse is in fair/poor health } & -- & 0.010 & 0.009 \\
\hline & -- & $(0.027)$ & $(0.027)$ \\
\hline \multirow[t]{2}{*}{ Spouse’s current earnings } & -- & 0.000 & 0.000 \\
\hline & -- & $(0.000)$ & $(0.000)$ \\
\hline
\end{tabular}

-cont'd- 


\begin{tabular}{lccc}
\hline Variables & Shocks only & $\begin{array}{c}\text { Shocks, initial } \\
\text { conditions } \\
\text { demographics }\end{array}$ & $\begin{array}{c}\text { Shocks, initial } \\
\text { conditions, } \\
\text { demographics } \\
+ \text { new job }\end{array}$ \\
\hline Spouse provides HI coverage & -- & 0.015 & 0.015 \\
Spouse is working & -- & $(0.026)$ & $(0.026)$ \\
& -- & 0.027 & 0.027 \\
Presence of resident parent & -- & $(0.029)$ & $(0.029)$ \\
& -- & 0.018 & 0.021 \\
Cares for parent & -- & $(0.054)$ & $(0.054)$ \\
& -- & 0.007 & 0.003 \\
Is a grandparent & -- & $(0.031)$ & $(0.031)$ \\
Wealth-related initial conditions & -- & -0.004 & -0.010 \\
Current earnings & -- & $(0.023)$ & $(0.023)$ \\
Pension income & & & -0.000 \\
Financial wealth & -- & -0.000 & $(0.000)$ \\
Miscellaneous controls & -- & $(0.000)$ & 0.002 \\
War baby cohort & -- & 0.002 & $(0.002)$ \\
Demographic controls? & -- & $(0.002)$ & -0.000 \\
Observations & -- & -0.000 & $(0.000)$ \\
\hline
\end{tabular}

Note: ${ }^{*} \mathrm{p}<0.05,{ }^{* *} \mathrm{p}<0.01,{ }^{* * *} \mathrm{p}<0.001$.

Source: Authors' estimates from the Health and Retirement Study, 1992-2012 waves. 
Table 6. Counterfactual Predictions of the Rate of Early Retirement

Shock $\quad$ \% retiring early \% change \% point difference

Prediction with actual data $37.0 \%$ $---\%$ $---\%$

Health

No health shock

No initial health problems

No health shocks or initial health problems

All retiree health insurance

$J o b$

No job change

No involuntary job loss

No job shocks

All "good" jobs

Family

No marital shock

No children leave home

No spouse retires

No spouse has fair/poor health shock

No parent moves in

No Rs begin caring for parent

No new grandparents

No family shocks

\section{Financial}

No financial gain

No financial loss

No financial shocks
35.4

33.8

32.2

37.4

37.8

35.0

37.0

34.1

36.6

36.8

36.2

36.8

36.8

37.2

36.9

35.4

36.3

36.1

35.4

$-4.4$

$-8.5$

$-12.9$

1.2

$-1.6$

$-3.2$

$-4.8$

0.4

2.1

0.8

$-5.3$

$-1.9$

0.1

0.0

$-7.9$

$-2.9$

$-1.0$

$-0.4$

$-0.5$

$-0.2$

$-2.2$

$-0.8$

$-0.5$

$-0.2$

$-0.4$

$-0.2$

0.6

0.2

$-0.3$

$-0.1$

$-4.2$

$-1.6$

\section{Cumulative}

No negative conditions

27.1

$-26.9$

$-9.9$

Notes: A “good” job is one with higher earnings, less stress, fewer hours, and less physical requirements than the age-58 wave job. "Negative conditions" include: health shock, initial health problems, retiree health insurance interaction, involuntary job loss, marital shock, children leaving home, spouse retiring, spouse has fair/poor health shock, parent moving in, becoming a grandparent, and financial shocks.

Source: Authors' calculations from the Health and Retirement Study, 1992-2012 waves. 


\section{RECENT WORKING PAPERS FROM THE CENTER FOR RETIREMENT RESEARCH AT BOSTON COLLEGE}

Calculating Neutral Increases in Retirement Age by Socioeconomic Status Geoffrey T. Sanzenbacher, Anthony Webb, Candace M. Cosgrove, and Natalia S. Orlova, August 2015

How Does Occupational Access for Older Workers Differ by Education? Matthew S. Rutledge, Steven A. Sass, and Jorge D. Ramos-Mercado, August 2015

How Much Longer Do People Need to Work?

Alicia H. Munnell, Anthony Webb, and Anqi Chen, August 2015

The Challenge of Pension Reform in Georgia: Non-Contributory Pensions and Elderly Poverty Tamila Nutsubidze and Khatuna Nutsubidze, July 2015

The Transition from Defined Benefit to Defined Contribution Pensions: Does It Influence Elderly Poverty?

Natalia S. Orlova, Matthew S. Rutledge, and April Yanyuan Wu, July 2015

Will the Average Retirement Age Continue to Increase?

Matthew S. Rutledge, Christopher M. Gillis, and Anthony Webb, July 2015

The Role of Occupations in Differentiating Health Trajectories in Later Life

Michal Engelman and Heide Jackson, University of Wisconsin-Madison, July 2015

The Relationship Between Automatic Enrollment and DC Plan Contributions: Evidence from a National Survey of Older Workers

Barbara A. Butrica and Nadia S. Karamcheva, July 2015

Evidence of Increasing Differential Mortality: A Comparison of the HRS and SIPP Barry P. Bosworth and Kan Zhang, July 2015

Slowed or Sidelined? The Effect of "Normal” Cognitive Decline on Job Performance Among the Elderly

Anek Belbase, Mashfiqur R. Khan, Alicia H. Munnell, and Anthony Webb, June 2015

Does Social Security Continue to Favor Couples?

Nadia S. Karamcheva, April Yanyuan Wu, and Alicia H. Munnell, June 2015

Sources of Increasing Differential Mortality Among the Aged by Socioeconomic Status Barry P. Bosworth, Gary Burtless, and Kan Zhang, June 2015

All working papers are available on the Center for Retirement Research website (http://crr.bc.edu) and can be requested by e-mail (crr@bc.edu) or phone (617-552-1762). 